\title{
Allelopathic potential of Equisetum giganteum L. and Nephrolepis exaltata L. on germination and growth of cucumber and lettuce
}

\author{
Danilo Miralha Franco ${ }^{1,3}$, Luiz Fernando Rolim de Almeida ${ }^{1}$, Rodrigo de Souza Poletto ${ }^{2,3}$ \\ ${ }^{1}$ Department of Botany, Instituto de Biociências, State University of Sao Paulo (UNESP), Botucatu/São Paulo, Brazil \\ ${ }^{2}$ North of Parana State University (UENP), Cornélio Procópio/Paraná, Brazil \\ ${ }^{3}$ Universidade Paulista (UNIP), Assis/São Paulo, Brazil
}

Email address:

francodm@ibb.unesp.br (D. M. Franco), luizfernando@ibb.unesp.br (L. F. R. Almeida), rodrigopoletto@uenp.edu.br (R. S. Poletto)

\section{To cite this article:}

Danilo Miralha Franco, Luiz Fernando Rolim de Almeida, Rodrigo de Souza Poletto. Allelopathic Potential of Equisetum giganteum L. and Nephrolepis exaltata L. on Germination and Growth of Cucumber and Lettuce. Journal of Plant Sciences. Vol. 2, No. 5, 2014 , pp. $237-241$. doi: $10.11648 /$ j.jps.20140205.24

\begin{abstract}
Nephrolepis exaltata L. Schott "Bostoniensis" family Davalliaceae and Equisetum giganteum L. family Equisetaceae, Phylum Pteridophyta, exhibit a strong mechanism of dominance in the areas in which they live. Have secondary compounds with allelopathic activity. The objective of this article was evaluate allelopathic potential of two ferns species, using bioassay applying aqueous extracts of dried fronds, in cucumber and lettuce seeds, and observing germination and initial development. To observe the influence on germination was analyze the percentage of germinated seeds and germination speed index (GSI). To observe initial development was analyzed shoot and root growth of the seedlings. The bioassays revealed that no concentration significantly inhibited the germination, but germination speed was delayed gradually in two species tested, as increased the extract concentration. In initial development, all the extracts showed a tendency to inhibit the growth, and an increase in extract concentration decreasing growth of radicle and hypocotyl axis. We conclude that the aqueous extract has inhibitory activity more pronounced in early development than in seed germination, affecting the primary structures of the tested plants, corroborating with the observations of occurrences of the species in natural places where dominate and suppress the growth of other species.
\end{abstract}

Keywords: Root Development, Germination, Crude Extract, Equisetum giganteum, Nephrolepis exaltata

\section{Introduction}

Plants present a diversity of chemical substances, possibly originating from evolutionary processes in response to the action of microorganisms, insects, viruses, other pathogens and plant-plant interactions [1]. This chemical diversity composed in response to different factors is known as allelopathy [2] and describes the influence of plant on others organisms, inhibiting or promoting development, suggesting that the effect is done by biomolecules (allelochemicals) produced by the secondary metabolism of the plant and released into the environment [3].

Metabolites released into the environment have an important function in the ecosystem, acting as signaling, defense and growth inhibition substances [4]. The visible effect of allelochemicals in plants is a secondary signaling change at molecular and cellular level $[5,6]$. The mode of action may be direct, through which the substance interferes with plant metabolism, or indirectly, where the allelopathic compound can change some properties of the soil [7].

Pteridophytes exhibit a pattern of dominance in the environment where they grow, forming almost pure associations, in which only a few species coexist. According to Francescato et al. (2013) [8] pteridophytes have substances that interfere in germination and growth of other plant species.

In this paper, we analyze two species of pteridophyte group in order to observe the allelopathic potential of a species found in almost pure associations areas near water (Equisetum giganteum) and other cultivated (Nephrolepis exaltata), known for their medicinal properties and high potential to inhibit the development of other species. 


\section{Materials and Methods}

Equisetum giganteum (a wild specie) and Nephrolepis exaltata (cultivated specie) green fronds, stems and rhizomes were collected and dried in oven at $40^{\circ} \mathrm{C}$ for $48 \mathrm{~h}$, and were subjected to extraction with water at $25^{\circ} \mathrm{C}$ in the ratio of $1 \mathrm{~g}$ of dried leaves into $10 \mathrm{ml}$ of water, and subjected to dynamic maceration for two hours. After the material was filtered, the procedure was repeated twice, getting Equisetum giganteum Extract (EEG) and Nephrolepis exaltata Extract (ENE).

For biological assays, was used cucumber and lettuce commercial seeds $\left(\right.$ Feltrin $^{\circledR}$ ), with $99 \%$ of germination rate. Were prepared stock solutions with EEG and ENE, diluted in concentrations of $25,50,75$, and $100 \%$, when $100 \%$ were $1 \mathrm{~g}$ of the extract for $10 \mathrm{ml}$ of water. The seeds were germinated in Petri dishes $\varnothing 9 \mathrm{~cm}$, with $10 \mathrm{ml}$ of each stock solution; and a control was performed using deionized water. The seeds were kept in growth chamber with 12:12 h light/dark photoperiod at $25^{\circ} \mathrm{C}$. After 5 days in growth chamber, the following parameters were analyzed: germination speed index (GSI), root growth and shoot growth. GSI was calculated by the following equation:

$$
G S I=\left(\frac{G 1}{N 1}\right)+\left(\frac{G 2}{N 2}\right)+\left(\frac{G 3}{N 3}\right)+\cdots+\left(\frac{G n}{N n}\right)
$$

$\mathrm{G} 1, \mathrm{G} 2, \mathrm{G} 3, \ldots, \mathrm{Gn}=$ number of seedlings computed in the first, second, third and last count.

$\mathrm{N} 1, \mathrm{~N} 2, \mathrm{~N} 3, \ldots, \mathrm{Nn}=$ number of days from seeding to first, second, third and last count.

Statistical analysis: The results are presented as means \pm standard deviations (SD) percentage relative to control. Statistical comparisons were performed by one-way ANOVA analysis of variance complemented by Tukey's test. Statistical significance was set at $\mathrm{P}<0.05$. Sigma Plot version 12.0 was used for graphic design and statistics.

\section{Results and Discussion}

Bioassays of germination and early development on lettuce and cucumber showed that EEG and ENE showed no inhibitory effect on seed germination of lettuce and cucumber, because reached $100 \%$ of the seeds germinated during the evaluation period.

However, it can be observed in figure 1 that, the germination speed of lettuce has inhibitory effect by EEG in concentrations of 75 and $100 \%$, but did not have same effect on cucumber. Already ENE showed inhibitory effect on germination speed of lettuce by concentration of $100 \%$, and in cucumber, all concentrations showed inhibitory effect relative to control.

Ahn and Chung (2000) [9], showed that aqueous extract of cultivars of Oryza sativa L. inhibited the germination of Echinochloa crusgalli. While Malheiros and Peres (2001) [10], showed that the aqueous extract of rhizome, green fronds and dried fronds of Gleichenia pectinata cause a germination speed decrease in Clidemia hirta, however, observed a significant increase in germinated seeds number in the final analysis of the experiment.

In figure 1 we can see a decrease in germination speed index (GSI), that may occur due to the allelochemicals compounds activity, that affect the mechanisms of cell division and elongation. It is observed, after the second day, germination reaches a comparable index relative to control, and until the end of the evaluation all seeds germinated. This can occurs through the cell detoxification process, which prevents the effect of inhibitory substances through enzymes of oxidative metabolism [11].

Delachiave et al. (1999) [12], showed that extract of shoot, root and whole plant of Cynodon dactylon also reported decrease in germination in cucumber. Already Peres et al. (2004) [13], in studies with 5 species of family Pteridaceae (Adiantopsis radiata, Adiantum serratodentatum, Adiantum tetraphyllum, Petris denticulata and Ptyrogramma calomel), it was concluded that none of the crude extracts showed significant effects on the germination of lettuce seeds, but sometimes it was observed a decrease in germination speed.

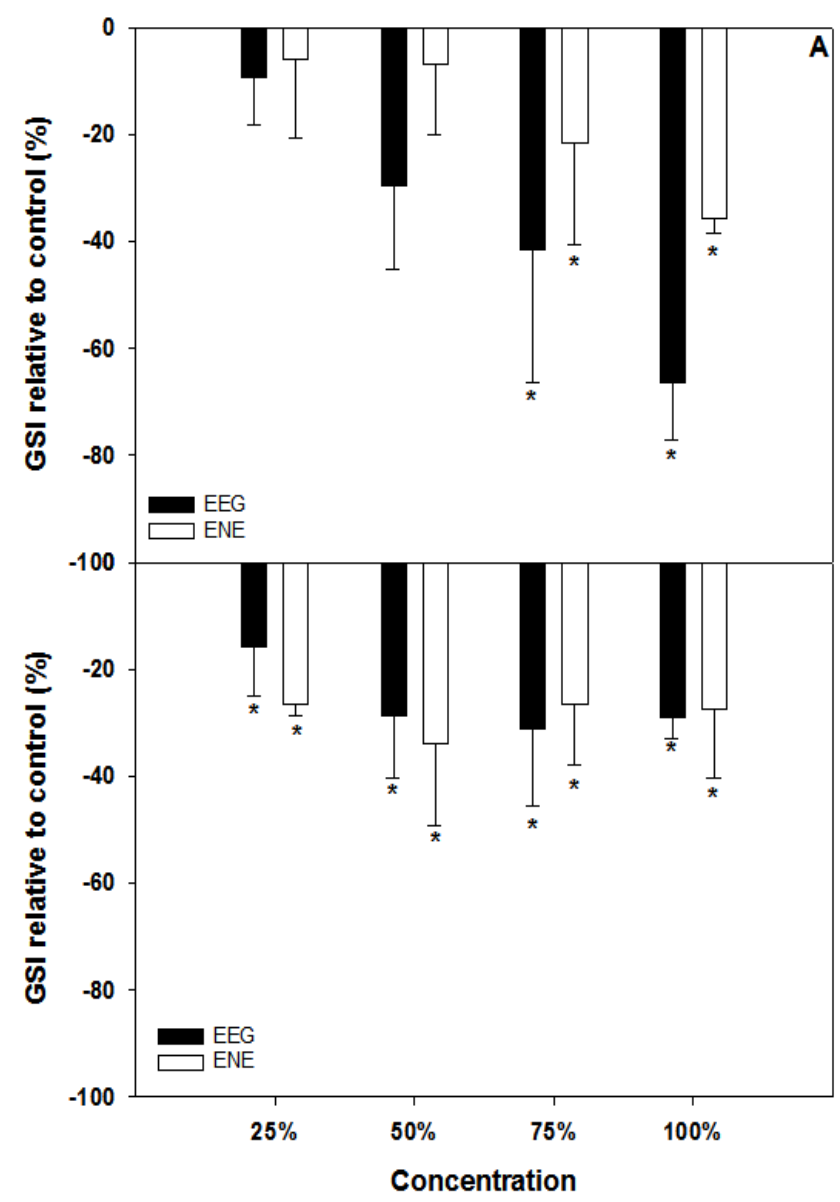

Figure 1. Germination speed index (GSI) of A: lettuce and B: cucumber seeds in response to EEG and ENE treatments and concentrations. * Level of significance $p<0.05$ by ANOVA followed by Tukey test.

Inderjit and Keating (1999) [14], emphasizes in his work that seedling growth is more widely used to assess allelopathy effects in vitro bioassays, that germination itself, perhaps because they are more sensitive to allelochemicals activity.

Analysis of initial growth development, show that chemical 
compounds activity have a constant inhibition dose related on lettuce, caused both by EEG and ENE. Lettuce is a species known as sensitive to allelochemicals, as cited by Hoagland and Williams (2004) [11], and demonstrated constant inhibition on development caused by allelopathic substances.

In cucumber, results (figure 2) show stimulus in root growth in treatments with lower concentrations of 25 and $50 \%$ of EEG and ENE, and inhibitory activity in treatments with higher concentrations (75 and 100\%). Mathematical adjustment models [15], demonstrated that some species at low concentrations of allelochemicals, present stimulation in biological response in germination, development or even the attraction of pollinators. In contrast, in high concentrations are visible the inhibition of biological processes.

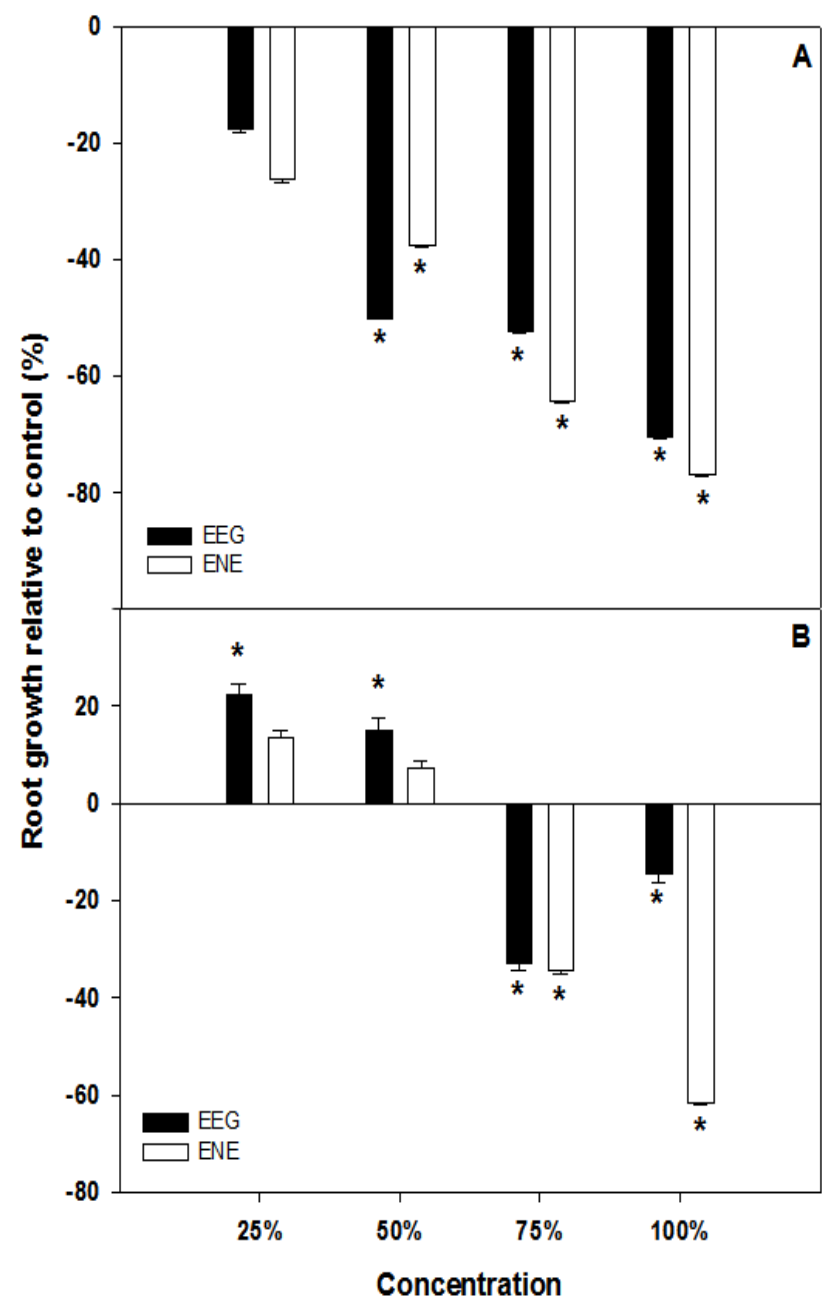

Figure 2. Root growth relative to control of A: lettuce and B: cucumber seeds in response to EEG and ENE treatments and concentrations. * Level of significance $p<0.05$ by ANOVA followed by Tukey test.

In shoot development (figure 3), we observe a growth stimulus in lettuce, in treatments with EEG in concentration of $25 \%$, and with ENE at concentrations of 25 and $50 \%$, and growth inhibition in treatment with the other concentrations. In cucumber, we observed a growth stimulus in plants treated with lower concentrations of 25 and $50 \%$, and inhibition with higher doses caused by EEG and ENE.

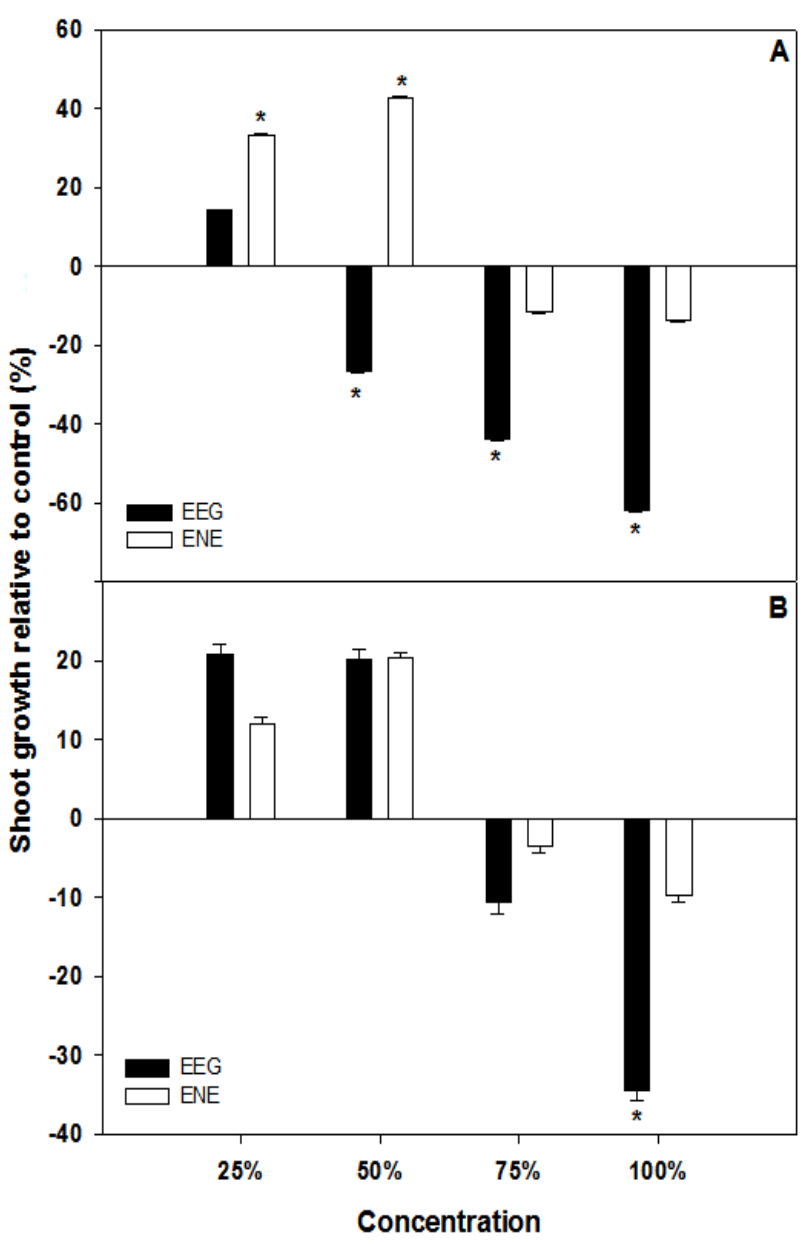

Figure 3. Shoot growth relative to control of A: lettuce and B: cucumber seeds in response to EEG and ENE treatments and concentrations. * Level of significance $p<0.05$ by ANOVA followed by Tukey test.

EEG has a higher inhibitory potential compared to ENE, fact associated with the substances that compose and by medicinal use. The presence of compounds with medicinal properties is an indicator of allelopathic activity [16]. This species is widely used in folk medicine throughout South America and in chemical composition is reported the presence of alkaloids, nicotine, as well as flavonoids such as apigenin, quercetin and kaempferol; and derivatives of chlorogenic acid, caffeic acid, tartaric acid, besides the tiaminase enzyme [17].

The difference of a crop plant and the other be collected in their natural environment, can have an influence in the production of secondary metabolites. Therefore, metabolites released in the medium, present important ecosystem function, acting as signaling substances, defense and inhibition of growth for other organisms [18].

Ferns have phenolic compounds in chemical composition, as flavonoids [8]. Flavonoids at low concentrations can stimulate root growth; however at high concentrations can inhibit [6]. Flavonoids assume negative charge at neutral $\mathrm{pH}$ in the intracellular medium, at low concentrations can promote cell growth by increasing enzymes, proteins and carriers of electrons efficiency; however, in high concentrations, can hyperpolarize membranes, altering the ATP pumps operation, characterizing flavonoids as toxic to 
the cells [19]. Also Franco et al. (2015) [5], demonstrated that flavonoids alter the expression of genes related to early development of roots, delaying development.

Rootlet emergence occurs at the expense of seed reserves and are therefore less sensitive to presence of allelochemicals than early growth. What determines an important ecological aspect, since there is inhibition of root system development, there is also a reduction in competitive pressure of plant in environment, which favors the neighboring species, which can develops aspects of dominance $[7,20]$.

Both species tested, although they are of the same group (Pteridophyte), showed different behavior relative to the effects on the germination and growth of the species tested. This can be explained by the fact that collection occurs in different and distinct location, one collected in natural environment and the other ornamental origin. This demonstrates that the amount of secondary metabolism substances may be different for each species. We show that the same extract presented different results on the germination and growth of the species tested, which can be explained by the fact that lettuce be more sensitive to chemical compounds than cucumber. Kato-Noguchi et al. (2013) [21], showed that Gleichenia japonica have compounds may contribute to the allelopathic effects involved in the formation of pure colonies of this fern specie.

With the results obtained, we conclude that the aqueous extract have inhibitory activity more pronounced in early development than in seed germination, affecting the primary structures of the tested plants, corroborating with the observations of occurrences of the species in natural places where dominate and suppress the growth of other species, contributing to formation of pure colonies.

\section{Acknowledgements}

A special thanks to Gislene Parreiras Costa for their help with the experiments, and to Universidade Paulista (UNIP) for support and infrastructure.

\section{References}

[1] Waller, G. R. 1989. Biochemical frontiers of allelopathy. Biologia Plantarum. 31, 418-447.

[2] Rice, E.L. Allelopathy. 2a Ed. Orlando, Florida: Academic Press. 1984. 422p.

[3] Rizvi, S. J. H.; Rizvi, V. Exploration of allelochemicals in improving crop productivity. In: RIZVI, S. J. H.; RIZVI, V. (Eds.) Allelopathy: Basic end applied aspects. London: Chapman \& Hall, 1992, 443-472.

[4] Lotina-Hennsen, B., Mata, R., Calderon, J., Cespedes, C., Jimenez, M. 1998. Secondary metabolites isolated from Mexican plants: Target and mechanism of action on photosynthesis. Recent Research Development in Agricultural \& Food Chemistry. 2, 731-749

[5] Franco, D.M., Saldanha, L.L., Silva, E.M, Nogueira, F.T.S., Dokkedal Bosqueiro, A.N. and Almeida, L.F.R. 2015. Leaves extracts of Myrcia guianensis affect growth and gene expression related with root development in Sorghum bicolor. Allelopathy Journal. 35, Accepted 2014.

[6] Weston, L.A., Mathesius, U. 2013. Flavonoids: Their Structure, Biosynthesis and Role in the Rhizosphere, Including Allelopathy. Journal of chemical ecology. 39 (2), 283-297.

[7] Ferreira, A.G.; Aquila, M.E.A. 2000. Alelopatia: Uma área emergente da ecofisiologia. Revista Brasileira de Fisiologia Vegetal, 12, 204-175.

[8] Francescato, L.N., Debenedetti, S.L., Schwanz, T.G., Bassani, V.L., Henriques, A.T. 2013. Identification of phenolic compounds in Equisetum giganteum by LC-ESI-MS/MS and a new approach to total flavonoid quantification. Talanta. 105, 192-203.

[9] Ahn, J.K., Chung, I.M. 2000. Allelopathic potential of rice hulls on germination and seedling growth of barnyardgrass. Agronomy Journal. 92, 1162-1167.

[10] Malheiros, A. and Peres, M.T.L.P. 2001. Alelopatia: interações químicas entre espécies. In: Calixto, J.B., Yunes, R.A. (Eds.) Plantas medicinais sob a ótica da química moderna. Ed. Argos: 503-523.

[11] Hoagland, R.E., Williams, R.D. 2004. Bioassays-useful tolls of the study of allelopathy. In: Macias, F.A. et al. (Eds.) Allelopathy: Chemistry and mode of action of allelochemicals. Boca Raton, Florida: CRC Press. 315-41.

[12] Delachiave, M.E.A., Ono, E.O., Rodrigues, J.D. 1999. Efeitos alelopáticos de grama-seda (Cynodon dactylon (L.) Pers.) na germinação de sementes de pepino, milho, feijão e tomate. Revista Brasileiras de Sementes. 21, 194-97.

[13] Peres, M.T.L.P., Silva, L.B., Faccenda, O., Hess, S.C. 2004. Potencial alelopático de espécies de Pteridaceae (Pteridophyta). Acta Botanica Brasílica. 18(4), 723-730.

[14] Inderjit and Keating, K.I. 1999 Allelopathy: principles, procedures, processes, and promises for biological control. Advances in Agronomy. 67, 141-231.

[15] An, M., Wagga, W. 2005. Mathematical modeling of dose-response relationship (Hormesis) in: allelopathy and its interpretation. Nonlinearity in Biology, Toxicology and Medicine. 3, $153-172$.

[16] Mathela, C.S. (1991) Allelochemicals in Medicinal and Aromatic Plants. In: Narwal, S.S., Tauro, P., editors. Allelopathy in agriculture and forestry. Jodhper (India): Scientific Publishers. p. 213-228.

[17] Lorenzi, H., Matos, J. A. Plantas medicinais no Brasil: nativas e exóticas cultivadas. Nova Odessa: Instituto Plantarum. 2002, $512 \mathrm{p}$.

[18] Larcher, W. Ecofisiologia Vegetal. São Carlos: Rima. 2000. $531 \mathrm{p}$.

[19] De Martino, L., Mencherini, T., Mancini, E., Aquino, R.P., Almeida, L.F.R., De Feo, V. 2012 In Vitro Phytotoxicity and Antioxidant Activity of Selected Flavonoids. International Journal of Molecular Sciences. 13, 5406-5419.

[20] Prates, H.T., Paes, J.M.V., Pires, N.M., Pereira Filho, I.A., Magalhães, P.C. 2000. Efeito do extrato aquoso de Leucena na germinação e no desenvolvimento do milho. Pesquisa Agropecuária Brasileira. 35, 909-914. 
[21] Kato-Noguchi, H., Saito, Y., Ohno, O., Suenaga, K. 2013.

Allelopathy is involved in the formation of pure colonies of the fern Gleichenia japonica. Journal of Plant Physiology. 170, 577-582. 